\title{
Digitalisasi Tuturan Psikogenik Latah (Kajian Fonetik Akustik)
}

\author{
Habib Rois \\ Pendidikan Bahasa dan Sastra Indonesia Universitas Muhammadiyah Jember \\ habibrois98@gmail.com
}

DOI: http://dx.doi.org/10.32528/bb.v5i1.2863

Diterima: 10-01-2020

Diterbitkan: 29-02-2020

\begin{abstract}
ABSTRAK
Tuturan psikogenik latah merupakan salah satu gangguan dalam berbahasa. Gangguan berbahasa pada tingkat psikogenik latah dapat disembuhkan dengan mengetahui pola-pola tuturan yang diproduksi oleh penderita latah. Berkaitan dengan hal tersebut, tujuan dalam penelitian ini adalah mendeskripsikan pola tuturan latah dengan menggunakan kajian fonetik akustik. Jenis penelitian yang digunakan adalah kualitatif deskriptif dengan menggunakan metode penelitian dari Institut voor Perceptie Onderzoek (IPO). Teori IPO merupakan kajian yang menganalisis fonetik secara linguistic science. Tuturan latah [tutup e tutup] merupakan bentuk tuturan yang dikaji secara akustik. Bentuk analisis digunakan terdiri dari tiga jenis pengukuran, yaitu pengukuran durasi, pengukuran frekuensi fundamental, dan pengukuran intensitas bunyi. Pada segmen bunyi vokoid /e/ secara durasi memiliki nilai yang relatif kecil, akan tetapi secara frekuensi memiliki nilai yang besar yaitu $391.828 \mathrm{~Hz}$. Selain itu, pengukuran intensitas bunyi pada segmen kedua bunyi vokoid /e/ memiliki nilai yang lebih besar di antara segmen lainnya, sebesar $80.451 \mathrm{~dB}$. Bunyi vokoid /e/ memiliki nilai frekuensi dan intensitas yang besar karena secara artikulatoris, besarnya frekuensi fundamental berkorespondensi dengan getaran pita suara. Peningkatan ini diakibatkan oleh adanya getaran pita suara yang lebih cepat dibanding pada saat pengucapan tuturan pada segmen satu yaitu kata/tutup/ dan segmen ketiga pada kata/tutup/ yang merupakan kata terakhir tuturan [tutup e tutup]. Berdasarkan uraian di atas maka bentuk tuturan latah Echolalia pada umumnya memiliki pola [silaba/kata]+[vokoid netral $]+[$ silaba/kata]. Perbedaan pola pada tuturan lain hanya berkaitan dengan jumlah kata yang diulang-ulang, secara garis besar bunyi vokoid netral berperan sebagai puncak intensitas tuturan latah Echolalia.
\end{abstract}

Kata Kunci : Psikogenik Latah; Fonetik Akustik; dan Teori IPO

\begin{abstract}
Psychogenic speech is one of the disorders in language. Language disorders at the talkative psychogenic level can be cured by knowing speech patterns produced by talkative sufferers. In this regard, the purpose of this study is to describe the talkative speech patterns using acoustic phonetic studies. This type of research is descriptive qualitative
\end{abstract}


using research methods from the Institute voor Perceptie Onderzoek (IPO). IPO theory is a study that analyzes phonetics in linguistic science. Latah speech [tutup e tutup] is a form of speech that is studied acoustically. The form of analysis used consists of three types of measurements, namely measurement of duration, measurement of fundamental frequency, and measurement of voice intensity. In the voidoid /e/ voice segment the duration has a relatively small value, but frequency has a large value that is $391,828 \mathrm{~Hz}$. In addition, the measurement of voice intensity in the second segment of voidoid /e/ voice has a greater value than the other segments, amounting to 80,451 $\mathrm{dB}$. Voidoid voice /e/ has a large value of frequency and intensity because artically, the magnitude of the fundamental frequency corresponds to the vibration of the vocal cords. This increase was caused by the vibration of the vocal cords that were faster than when speaking utterances in segment one namely the word /tutup/ and the third segment in the word /tutup/ which is the last word of the speech [tutup e tutup]. Based on the description above, Echolalia's latah speech form generally has a pattern of [silaba / word] + [neutral voidoid] + [silaba / word]. The difference in patterns in other speeches is only related to the number of words that are repeated, in general the neutral vocoid voice acts as the peak intensity of Echolalia talkative speech.

Keywords: Talkative Psychogenic; Acoustic Phonetics; IPO Theory

\section{PENDAHULUAN}

Komunikasi merupakan proses penyampaian sebuah makna melalui tuturan antara penutur dengan mitra tutur. Pada proses komunikasi, terdapat beberapa kesalahpahaman akan memaknai sebuah ujaran, dikarenakan adanya beberapa gangguan. Salah satu gangguan berbahasa adalah psikogenik. Psikogenik merupakan gangguan fungsional yang diakibatkan oleh konflik atau tekanan emosional yang meliputi berbicara manja, berbicara kemayu, berbicara gagap, dan berbicara latah (Hermawan, 2016, hal. 2). Psikogenik pada dasarnya merupakan gangguan mental pada seseorang yang mengalami tekanan emosi, sehingga memungkinkan untuk memproduksi tuturan yang dirasa kurang normal. Adapun jenis psikogenik yang dikaji dalam penelitian ini adalah berbicara latah.

Latah adalah suatu gangguan kebahasaan, di mana seseorang mampu mengeluarkan kata-kata secara spontan dan berulang-ulang tanpa disadari (Dardjowidjojo, 2016, hal. 154). Ganguan psikogenik latah merupakan kajian yang menarik untuk diteliti, karena latah merupakan fenomena yang lazim dialami oleh sebagain orang. Kebiasaan latah dapat muncul ketika mendengar atau melihat sesuatu yang bersifat spontan. Fatmawati \& Mintowati (2018, hal. 2), menyatakan bahwa jenisjenis psikogenik latah dibagi menjadi empat, meliputi : coprolalia, echolalia, echopraxia, dan automatic obedience. Jenis latah yang peneliti gunakan hanya pada latah echolalia.

Latah echolalia merupakan salah satu jenis latah yang sering terjadi pada penderita psikogenik latah. Kebiasaan latah echolalia dapat muncul ketika seseorang mendengar atau melihat sesuatu yang bersifat spontan dan menirukan kata yang 
didengarnya dengan diucapkan secara berulang-ulang. Penderita latah pada umumnya dapat disembuhkan atau dikurangi kebiasaan tersebut dengan adanya pengaruh dari lingkungan, salah satunya adalah di dunia Pendidikan.

Pada lingkungan Pendidikan, kebiasaan latah seseorang dapat disembuhkan atau dikurangi melalui bentuk-bentuk pembelajaran yang dikemas oleh guru mata pelajaran. Pada kehidupan sehari-hari, masih banyak siswa yang mengalami gangguan psikogenik latah yang dikarenakan oleh banyak faktor. Gangguan latah ini dapat meningkat jika faktor lingkungan mendukung untuk terus berperilaku latah, untuk itu peran guru dalam mengurangi gangguan latah siswa sangat diperlukan. Intonasi dalam memberikan sebuah materi di dalam kelas juga dapat mempengaruhi perilaku latah siswa, karena pada dasarnya latah dapat muncul ketika seorang penderita merasa terkejut atau dikejutkan. Sebagai contoh, pada konteks aktivitas siswa di kelas, khususnya ketika siswa menyuruh kepada siswa lain yang menderita latah dengan intonasi yang tinggi dan berkata "tutup kepalamu!", secara refleks siswa yang selaku mitra tutur akan merasa terkejut dan mengulangi kata-kata yang didengarkan dengan tuturan [tutup eh tutup].

Berkaitan dengan hal tersebut, tentunya memberikan tantangan tersendiri bagi pendidik untuk dapat menerapkan pembelajaran yang efektif tanpa ada gangguangangguan ketika proses kegiatan belajar mengajar. Kebiasaan latah juga menjadi salah satu bentuk gangguan ketika proses pembelajaran di kelas, untuk itu peran guru dalam mengurangi kebiasaan tersebut sangat diperlukan. Bentuk kajian yang cukup efisien untuk mengidentifikasi tuturan penderita latah adalah dengan menggunakan cabang linguistik fonologi, tepatnya pada kajian fonetik akustik.

Fonetik akustik digunakan untuk mencari struktur gelombang bunyi yang muncul dari tuturan seseorang penderita latah. Proses digitalisasi untuk melihat frekuensi tuturan menggunakan perangkat lunak Praat 6-0-33. Praat 6-0-33 merupakan sebuah perangkat lunak komputer yang dibuat untuk menganalisis tuturan fonetik. Melalui proses digitalisasi dengan menggunakan aplikasi Praat 6-0-33, tuturan psikogenik latah lebih mudah untuk diidentifikasi baik dari segi persamaan maupun perbedaan tuturan. Melalui visualisasi dari sebuah tuturan pada aplikasi Praat 6-0-33, peneliti lebih mudah untuk mengukur artikulasi, akustik, dan jumlah pendengaran yang meliputi periode glottal, frekuensi resonansi, durasi, intensitas, kebisingan, dan tempat artikulasi.

Berdasarkan latar belakang di atas, tujuan dalam penelitian ini adalah mendeskripsikan pola tuturan psikogenik latah berdasarkan kajian fonetik akustik melalui aplikasi Praat 6-0-33.

Pada penelitian sebelumnya oleh Fatmawati \& Mintowati (2018) yang berjudul "Gangguan Berbahasa Jenis Psikogenik Latah: Studi Kasus Di Desa Tropodo Kecamatan Waru Kabupaten Sidoarjo”, hanya memfokuskan pada gangguan psikogenik latah melalui kajian psikolinguistik. Kajian psikolinguistik pada penelitian Fatmawati \& Mintowati (2018) bertujuan untuk mengetahui faktor psikologis yang menyebabkan gangguan psikogenik latah. Hal ini yang menyebabkan peneliti mengkaji sebuah gangguan bahasa psikogenik latah menggunakan kajian fonetik akustik. 
Marsono (2018, hal. 2) menyatakan bahwa fonetik akustik merupakan kajian yang mempelajari bunyi bahasa dari segi bunyi sebagai gejala fisis. Gejala fisis tersebut meliputi frekuensi getaran, amplitudo, intensitas, dan timbrenya. Wujud bunyi dalam kajian fonetik akustik divisualisasikan ke dalam spektrum, waveform atau spektogram. Pada waveform atau spektogram adanya energi bunyi dalam suatu tuturan ditandai dengan gumpalan-gumpalan yang berwarna hitam. Sedangkan gumpalan-gumpalan berwarna putih menandakan tidak adanya energi bunyi pada tuturan tersebut. Pada spektogram, energi bunyi semakin besar, maka gumpalan-gumpalan hitam semakin berwana pekat dan besar.

Bentuk visualisasi dari setiap jenis gelombang dapat berupa waveform dan spektrum. Bunyi dapat direpresentasikan sebagai suatu yang padu dengan waveform. Sedangkan gelombang bunyi dapat direpresentasikan sebagai sesuatu yang terdiri atas komponen-komponen dengan spektrum. Visualisasi dari setiap komponen tuturan dapat melalui perangkat lunak Praat 6-0-33. Aplikasi Praat 6-0-33 merupakan program yang digunakan untuk menganalisis fonetik berbasis aplikasi komputer. Proses analisis tuturan melalui aplikasi Praat 6-0-33 adalah dengan membaca waveform dan spektogram, pengukuran frekuensi, pengukuran intensitas, dan pengukuran durasi.

\section{METODE PENELITIAN}

Metode penelitian yang digunakan dalam penelitian ini merujuk pada ancangan IPO, yaitu sebuah ancangan yang didesain untuk menganalisis sinyal akustik. IPO (Institut voor Perceptie Onderzoek) adalah badan kerjasama yang didirikan dan dikembangkan oleh Eindhoven University of Technology dan Philips Research Laboratories pada tahun 1957 di Eindhoven, Belanda. Adapun hasil kerjasama tersebut berupa ancangan IPO atau disebut dengan teori IPO yaitu kajian yang menganalisis fonetik eksperimental.

Jenis penelitian yang digunakan dalam penelitian ini adalah deskripstif kualitatif. Hasil dari data yang diperoleh dalam penelitian ini berupa parameter akustik tuturan latah yang akan dianalisis secara deskriptif. Jenis penelitian kualitatif ini didasarkan pada bentuk data yang diteliti yaitu merujuk pada sebuah tuturan penderita psikogenik latah. Acuan utama yang digunakan pada penelitian ini adalah teori-teori fonetik akustik yang dikembangkan oleh Paul Boersma (2013).

Ruang lingkup pada penelitian ini merujuk pada sebuah tuturan psikogenik latah yang dituturkan dengan tanpa sengaja. Melalui objek tuturan ini, peneliti dapat menganalisis data melalui aplikasi Praat 6-0-33. Penggunaan aplikasi Praat 6-0-33 bertujuan untuk mendigitalkan sebuah tuturan dan memvisualisasikan output tuturan dalam bentuk gelombang atau sinyal akustik. Data yang digunakan dalam penelitian ini berupa sebuah tuturan psikogenik latah dalam bentuk video ( $\mathrm{mp} 4$ ) yang bersumber dari youtube. Tuturan latah yang dianalisis oleh peneliti tidak semua digunakan, akan tetapi peneliti hanya mengambil data yang mempunyai kualitas suara baik dan dapat diproses secara akustik. Proses akustik dalam hal ini merupakan analisis model gelombang tuturan. 
Peneliti memilih sumber data dari youtube dengan tujuan untuk mempermudah proses digitalisasi dan menghindari adanya manipulasi tuturan. Tuturan yang ada di dalam tayangan youtube juga menunjukkan kealamiahan dan kenaturalan dari data psikogenik latah echolalia. Bentuk analisis pada kajian fonetik akustik membutuhkan data suara yang mempunyai kualitas baik dan tidak dimanipulasi, sehingga bentuk gelombang yang divisualisasikan pada aplikasi Praat 6-0-33 dapat dianalisis secara akustik.

Jenis pengumpulan data yang digunakan dalam penelitian ini adalah dokumentasi. Dokumentasi video (mp4) diubah menjadi bentuk audio (wav) agar dapat dimasukkan ke dalam aplikasi Praat 6-0-33. Metode yang digunakan pada pengumpulan data ini menggunakan metode simak dengan teknik dasar sadap. Teknik sadap digunakan karena video yang digunakan, peneliti unduh melalui youtube dan diubah ke format sudio (wav). Setelah data terkumpul, maka langkah selanjutnya adalah teknik penganalisisan data.

Proses analisis data yang digunakan dalam penelitian ini meliputi : reduksi data, penyajian data, dan verifikasi data. Pada proses reduksi, peneliti memilih tuturan yang dapat dijadikan sebagai tuturan utama untuk dianalisis secara akustik dan termasuk ke dalam jenis latah echolalia. Pemilahan ini didasarkan pada sifat gelombang akustik yang peka terhadap noise dan mempunyai kualitas suara baik. Peneliti menggunakan data hasil reduksi yaitu pada tuturan [tutup e tutup]. Konteks tuturan tersebut diucapkan oleh siswa SMA yang sedang berkumpul dengan teman sekelasnya untuk foto selfie, dengan sengaja mitra tutur menyuruh siswa yang latah tersebut untuk menutupi rambutnya dengan kerudung. Spontan penderita psikogenik latah merasa terkejut dan mengucapkan tuturan latah [tutup e tutup].

Pada proses penyajian data, peneliti menggunakan metode padan intralingual dengan teknik hubung banding menyamakan hal pokok (HBSP). Metode padan intralingual digunakan karena model analisis yang digunakan dengan menghubungbandingkan unsur-unsur yang bersifat lingual untuk mencari kesamaan dan perbedaan secara spesifik antara pola kata pada tuturan latah. Bentuk analisis didasarkan pada bentuk gelombang akustik dalam aplikasi Praat 6-0-33. Bentuk visualisasi aplikasi Praat 6-0-33 ini menggunakan waveform dan spektogram. Waveform digunakan untuk mencari anotasi tuturan setiap jenisnya, sedangkan spektogram digunakan sebagai dasar untuk menganalisis pengukuran durasi, pengukuran frekuensi fundamental, dan pengukuran intensitas bunyi.

\section{HASIL DAN PEMBAHASAN}

Kajian fonetik akustik yang digunakan untuk mencari pola tuturan [tutup eh tutup] adalah dengan analisis akustik pada proses pengukuran durasi, pengukuran frekuensi fundamental, dan pengukuran intensitas bunyi. Pengukuran durasi bertujuan untuk mencari batas segmen setiap bunyi yang dituturkan. Pengukuran frekuensi digunakan untuk menganalisis kontur nada. Sedangkan pengukuran intensitas bunyi bertujuan untuk melihat lantang atau tingkat penekanan pada setiap segmen tuturan. Ketiga pengukuran tersebut lebih jelasnya diuraikan pada subbab berikut ini. 


\section{Pengukuran Durasi}

Pada sebuah tuturan, terdapat energi bunyi yang terdistribusi ke dalam dimensi waktu. Dimensi tersebutlah yang disebut dengan durasi. Durasi pada satuan tunggal disebut juga period yang dilambangkan dengan Time $(t)$ dengan satuan secon $(s)$. Durasi Pengukuran dimensi pada tuturan [tutup e tutup] dibagi menjadi tiga segmen. Ketiga segmen tersebut diuraikan pada gambar 1.

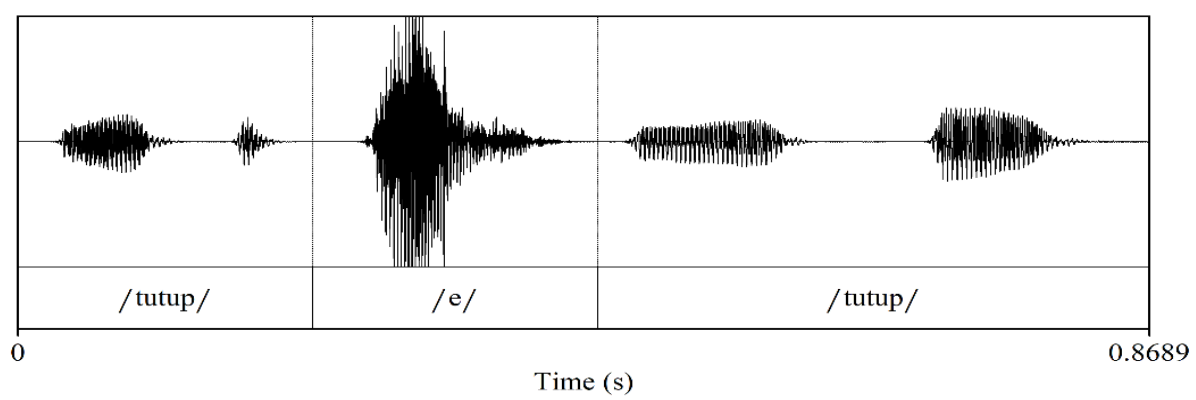

Gambar 1: Segmentasi sinyal akustik tuturan latah [tutup eh tutup]

Segmentasi ini diterapkan untuk mempermudah peneliti dalam menentukan batas waktu maksimal dan batas waktu minimal pada setiap tuturan. Tuturan [tutup $e$ tutup] terdiri dari tiga segmen yang menandakan pembagian durasi menjadi tiga bagian. Ketiga segmen tuturan Tuturan [tutup e tutup] meliputi 2 kata dan 1 bunyi vokoid. Adapun faktor yang mempengaruhi adanya durasi pada setiap tuturan antara lain : (1) faktor suprasegmental, (2) titik artikulasi dari setiap segmen, (3) suara-suara pengisi bunyi selanjutnya. Berkaitan dengan faktor-faktor tersebut, pada tuturan [tutup e tutup] didapat satuan durasi yang dilihat dari batas minimal dan batas maksimal, berikut tabel 1 merupakan hasil penghitungan durasi dari tuturan [tutup e tutup].

Tabel 1: Durasi Tuturan [tutup e tutup]

\begin{tabular}{ccccc}
\hline Tuturan & Kode & tMin & tMax & Durasi (s) \\
\hline /tutup/ & $\mathrm{S} 1$ & 0 & 0,223 & $0,223 \mathrm{~s}$ \\
\hline /e/ & $\mathrm{S} 2$ & 0,223 & 0,447 & $0,224 \mathrm{~s}$ \\
\hline /tutup/ & $\mathrm{S} 3$ & 0,447 & 0,869 & $0,422 \mathrm{~s}$ \\
\hline
\end{tabular}

Ketiga segmen tuturan /tutup/, /e/, dan /tutup/ memiliki bentuk durasi yang berbeda. Pada S1 tuturan /tutup/ berdurasi 0,223 s. Pada tuturan S2, yaitu pada bunyi vokoid /e/ berdurasi 0,224 s. Sedangkan pada S3 tuturan /tutup/ di akhir tuturan memiliki durasi 0,422. Berdasarkan penghitungan durasi ketiga segmen di atas, tuturan [tutup e tutup] memiliki perbedaan durasi setiap segmen yang semakin tinggi. Pada S1 dengan S2 memiliki selisih 0,001 s, jika dilihat dari bentuk tuturannya, S1 merupakan kata utuh yang memiliki struktur huruf paling banyak dibandingkan pada S2 yang hanya bunyi vokoid /e/. Hal ini menandakan bahwa bunyi vokoid pada tuturan latah cenderung diucapkan dengan durasi yang lebih panjang jika dibandingkan dengan kata yang berada sebelum bunyi vokoid. Pada umumnya, bunyi vokoid yang ada pada tuturan penderita 
latah adalah bunyi /e/, atau ada yang menambahkan dengan huruf konsonan $/ \mathrm{h} / \mathrm{sehingga}$ menjadi /eh/. Namun, pada penelitian ini data yang peneliti dapatkan memiliki bunyi vokoid /e/ yang diucapkan dengan durasi yang relatif panjang jika dibandingkan dengan tuturan atau kata sebelum bunyi vokoid.

Tuturan S3 yaitu /tutup/ yang merupakan kata terakhir dalam tuturan [tutup e tutup] yang memiliki satuan durasi terpanjang jika dibandingkan antara S1 dengan S2. Hadirnya S3 pada tuturan [tutup e tutup] menandakan kata yang menjadi fokus penderita latah untuk diucapkan dengan penekanan yang relatif rendah dan durasi yang lebih panjang. Panjangnya tuturan S3 dipengaruhi oleh adanya penekanan sebelumnya. Penekanan di bunyi vokoid merupakan titik puncak tuturan latah yang akan merujuk pada tuturan selanjutnya yang bersifat netral atau kembali ke titik nada awal.

Berdasarkan analisis pada aplikasi Praat 6-0-33 tuturan S3 memiliki durasi yang lebih panjang di antara bunyi yang lainnya, dikarenakan bunyi yang dituturkan oleh penderita latah cenderung di ayun-ayun, sehingga menghasilkan durasi yang lebih panjang. Pengayunan ini merupakan hasil refleks penderita latah yang menandakan bahwa tuturan tersebut merupakan bentuk penutup dari serangkaian tuturan latah yang diucapkan. Hasil penghitungan durasi pada tuturan [tutup e tutup] memiliki total durasi $0,869 s$ dengan adanya kenaikan hingga pada titik terakhir yaitu pada tuturan S3 sebesar $0,442 s$.

Istilah ayun-ayun pada hal ini peneliti bandingkan dengan senyapan dan kilir lidah. Adapun penelitian sebelumnya oleh Pangesti (2018) dengan judul "Senyapan dan Kilir Lidah Berdampingan dalam Produksi Ujaran" menyatakan bahwa terdapat senyapan terisi yang dicirikan dengan adanya bunyi vokoid /e/ di tengah-tengah tuturan. Beberapa jenis senyapan dan kilir lidah yang memproduksi bunyi vokoid /e/ diantaranya, freudian slip senyapan terisi, freudian slip, senyapan, kombinasi, blend senyapan terisi, dan antisipasi senyapan terisi. Namun, pada penelitian Pangesti (2018) tidak menyatakan adanya pengucapan tuturan yang diayun-ayun setelah adanya bunyi vokoid /e/.

Adanya pengayunan bunyi tuturan setelah bunyi vokoid /e/ tidak termasuk ke dalam jenis senyapan dan kilir lidah, akan tetapi istilah ayun-ayun pada hal ini merupakan temuan baru yang mencirikan tuturan psikogenik latah jenis Echolalia. Sedangkan pada bunyi vokoid /e/ ini dapat dikategorikan ke dalam jenis-jenis senyapan dan kilir lidah. Berdasarkan uraian di atas, tuturan latah Echolali memiliki pola yang sangat sistematis di dalam tataran durasi. Adanya tuturan durasi yang lebih panjang pada kata terakhir menunjukkan pengayunan pada kata tersebut. Serta, pengayunan bunyi ini cenderung diucapkan setelah adanya senyapan dan kilir lidah, tepatnya bunyi vokoid /e/.

\section{Pengukuran Frekuensi Fundamental}

Frekuensi fundamental hanya dapat dianalisis pada gelombang klompeks. Secara teknis pengukuran frekuensi fundamental dapat dilakukan secara manual maupun digital. Namun, cara digital lebih efektif untuk digunakan karena menampilkan hasil yang detail dan jelas. Analisis frekuensi fundamental berkaitan juga dengan analisis 
kontur nada, karena kedua bentuk ini saling melengkapi pada tahapan analisis frekuensi. Analisis kontur nada dalam penelitian ini bertujuan untuk melihat struktur nada berdasarkan keteraturan grafik pada kontur nada atau pitch. Sebelum melihat kontur nada pada tuturan [tutup e tutup], peneliti melakukan analisis bentuk tuturan yang bertujuan untuk menghilangkan noise yang ada pada tuturan dengan tidak merubah struktur bunyi lainnya. Penghilangan noise ini diterapkan agar pada penentuan frekuensi fundamental menghasilkan angka yang akurat dan bentuk tuturan yang bersih dari gangguan-gangguan suara lain atau noise. Berikut gambar 2 merupakan kontur nada pada tuturan [tutup e tutup].

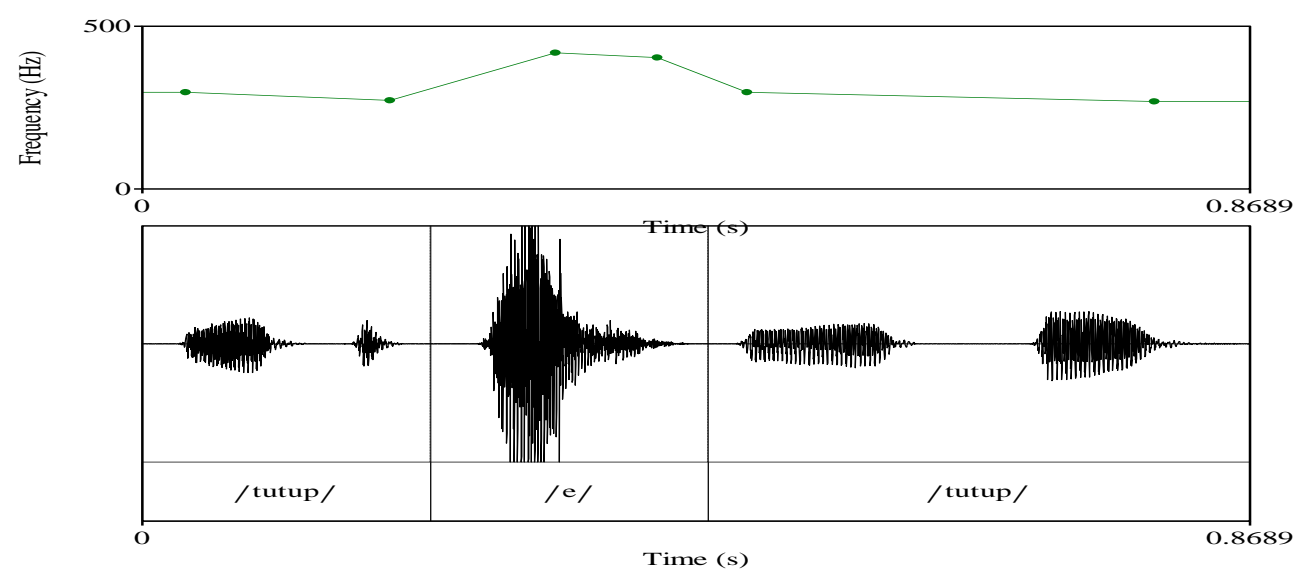

Gambar 2: Kontur nada tuturan [tutup e tutup]

Pada gambar 2 kontur nada pada tuturan [tutup e tutup] memiliki struktur nada yang cukup teratur. Tuturan pada S1 memiliki penurunan yang tidak terlalu signifikan, sedangkan pada S2 tepatnya pada bunyi vokoid /e/ struktur nada mengalami kenaikan satu gelombang yang signifikan. Perubahan struktur dari S1 terhadap S2 menandakan adanya penekanan pada pelafalan bunyi vokoid. Bunyi vokoid yang muncul merupakan tataran bunyi yang menunjukkan tingkat refleks paling tinggi pada tuturan penderita latah. Tentunya peningkatan struktur ini di dasarkan pada pola pelafalan yang menandakan adanya penekanan pada salah satu kata atau bunyi yang lain. Pada tuturan S3, struktur nada mengalami penurunan dan kembali ke titik netral yang sama dengan titik awal tuturan. Perubahan antar bunyi ini menandakan bahwa, tuturan latah yang berposisi di awal umumnya memiliki struktur nada yang normal. Adanya penekanan terjadi pada bunyi netral atau bunyi vokoid yang diucapkan oleh penutur latah. Sehingga letak penekanan merupakan puncak dari sebuah tuturan latah yang akan mengalami penurunan struktur dan kembali ke titik netral atau titik awal tuturan tersebut diujarkan. Pembagian segmen dengan frekuensi fundamental pada tuturan [tutup e tutup] terdapat pada tabel 2 berikut ini. 
Tabel 2: Frekuensi Fundamental Tuturan [tutup e tutup]

\begin{tabular}{cccc}
\hline Tuturan & Kode & $\begin{array}{c}\text { Durasi } \\
(\mathbf{s})\end{array}$ & $\begin{array}{c}\text { Frekuensi } \\
(\mathbf{H z})\end{array}$ \\
\hline /tutup/ & $\mathrm{S} 1$ & $0,223 \mathrm{~s}$ & $292.744 \mathrm{~Hz}$ \\
\hline /e/ & $\mathrm{S} 2$ & $0,224 \mathrm{~s}$ & $391.828 \mathrm{~Hz}$ \\
\hline /tutup/ & $\mathrm{S} 3$ & $0,422 \mathrm{~s}$ & $279.358 \mathrm{~Hz}$ \\
\hline
\end{tabular}

Berdasarkan data frekuensi fundamental, tuturan pada S1, S2, dan S3 memiliki perbedaan. Perbedaan ini menandakan adanya penekanan dari setiap tuturan. Tuturan S2 memiliki nilai frekuensi fundamental terbesar jika dibandingkan dengan tuturan S1 dan S3. Secara artikulatoris, besarnya frekuensi fundamental berkorespondensi dengan getaran pita suara yang disebut dengan fonasi. Peningkatan ini diakibatkan oleh adanya getaran pita suara yang lebih cepat dibanding pada saat pengucapan tuturan S1 dan S3. Selain itu, peningkatan frekuensi pada tuturan S2 diakibatkan oleh adanya tekanan udara di daerah subglotal yang meningkat, sehingga getaran pita suara semakin cepat. Adanya tekanan udara ini didasarkan pada hasil segmentasi bunyi /e/ pada tuturan [tutup e tutup] yang memiliki nilai frekuensi tinggi dan titik kontur nada yang meningkat.

\section{Pengukuran Intensitas Bunyi}

Pengukuran intensitas bunyi merupakan bentuk analisis untuk menentukan kelantangan bunyi dari setiap segmen pada tuturan [tutup e tutup]. Berikut tabel 3 merupakan nilai intensitas dari tuturan [tutup e tutup].

Tabel 3: Intentsitas bunyi tuturan [tutup e tutup]

\begin{tabular}{cccc}
\hline Tuturan & Kode & $\begin{array}{c}\text { Durasi } \\
(\mathbf{s})\end{array}$ & $\begin{array}{c}\text { Intensitas } \\
(\mathbf{d B})\end{array}$ \\
\hline /tutup/ & $\mathrm{S} 1$ & $0,223 \mathrm{~s}$ & $68.497 \mathrm{~dB}$ \\
\hline /e/ & $\mathrm{S} 2$ & $0,224 \mathrm{~s}$ & $80.451 \mathrm{~dB}$ \\
\hline /tutup/ & $\mathrm{S} 3$ & $0,422 \mathrm{~s}$ & $72.254 \mathrm{~dB}$
\end{tabular}

Bunyi-bunyi yang memiliki intensitas atau kelantangan tinggi umumnya berada pada bunyi vokoid. Adapun nilai intensitas pada tuturan [tutup e tutup] memiliki variasi yang sangat berbeda. Pada tuturan S2 memiliki nilai intensitas yang lebih tinggi dibanding dengan tuturan pada segmen lainnya. Tingginya intensitas ini menandakan bahwa pada tuturan S2 memiliki kelantangan bunyi yang tinggi.

Berdasarkan tabel 4.3, tuturan S2 memiliki nilai intensitas bunyi yang lebih tinggi dibandingkan dengan tuturan pada S1 dan S3. Tingginya tuturan S2 menandakan adanya kelantangan bahwa, bunyi tersebut diucapkan dengan nada naik dan penekanan yang kuat. Pada dasarnya intensitas suatu bunyi menandakan kelantangan dalam pengucapan yang dapat mempengaruhi daya dengar dari mitra tutur. Adanya penekanan 
pada tuturan S2 memberikan ciri khusus bahwa tuturan latah identik dengan adanya bunyi vokoid yang cenderung diucapkan dengan nada atau kelantangan yang tinggi.

\section{SIMPULAN}

Tuturan latah [tutup e tutup] merupakan bentuk refleks secara verbal dari seseorang yang mengalami latah echolalia. Latah echolalia merupakan gejala yang cenderung menirukan perkataan orang lain dengan mengulangi kata pokok yang menjadi bentuk refleks akibat merasa terkejut atau dikejutkan. Pola tuturan latah pada penelitian ini dikaji melalui tiga pengukuran, yaitu pengukuran durasi, pengukuran frekuensi fundamental, dan pengukuran intensitas bunyi. Pada pengukuran durasi, tuturan pada segmen terakhir yaitu pada kata /tutup/ memiliki nilai durasi yang lebih banyak jika dibandingkan dengan segmen 1 atau segmen 2. Panjangnya durasi ini menjadikan tuturan pada segmen ketiga lebih diayun-ayun. Adanya pengayunan tuturan pada segmen ketiga ini ditandai dengan hadirnya senyapan dan kilir lidah pada bunyi vokoid /e/. Sehingga pola yang menunjukkan tuturan latah psikogenik latah dipengaruhi oleh adanya senyapan dan kilir lidah. Bentuk pola yang merupakan ciri baru dari tuturan psikogenik latah jenis Echolalia adalah [kata]+[senyapan dan kilir lidah]+[pengulangan dan pengayunan kata awal].

Pada pengukuran frekuensi fundamental, segmen kedua pada bunyi vokoid /e/ memiliki nilai frekuensi yang lebih besar diantara segmen-segmen lainnya. Sedangkan pada pengukuran intensitas bunyi, tuturan pada segmen kedua memiliki nilai yang tinggi dibanding dengan segmen lainnya. Segmen kedua pada bunyi vokoid /e/, secara frekuensi dan intensitas memiliki keunggulan, itu sebabnya bahwa pola dari tuturan penderita latah memiliki penekanan pada bunyi netral atau bunyi vokoid di tengahtengah tuturan dengan durasi yang relatif pendek di antara segmen lainnya. Berdasarkan uraian di atas maka bentuk tuturan latah Echolalia pada umumnya memiliki pola [silaba/kata]+[vokoid netral]+[silaba/kata]. Perbedaan pola pada tuturan lain hanya berkaitan dengan jumlah kata yang diulang-ulang, secara garis besar bunyi vokoid netral berperan sebagai puncak intensitas tuturan latah Echolalia.

\section{DAFTAR RUJUKAN}

Boersma, P. (2013). Acoustic Analysis. Cambridge: Cambridge University Press.

Boersma, P., \& Weenink , D. (2018). Phonetic Sciences. Amsterdam: University of Amsterdam.

Chaer, A. (2009). Psikolinguistik : Kajian Teoretik. Jakarta: Rineka Cipta.

Chaer, A. (2012). Linguistik Umum. Jakarta: Rineka Cipta.

Dardjowidjojo, S. (2016). Psikolinguistik : Pengantar Pemahaman Bahasa Manusia. Jakarta: Yayasan Pustaka Obor Indonesia.

Fatmawati, N. P., \& Mintowati. (2018). Gangguan Berbahasa Jenis Psikogenik Latah : Studi Kasus di Desa Tropodo Kecamatan Waru Kabupaten Sidoarjo. Sapala, Vol 5, No.1.

Hermawan, N. F. (2016). Gangguan Psikogenik Orang Alay. El-Wasathiya, Vol. 4, No.2, hal. 115-128. 
Irawan, Y. (2017). Fonetik Akustik. Bandung: Angkasa.

Mahsun. (2012). Metode Penelitian Bahasa : Tahapan Strategi, Metode, dan Tekniknya. Jakarta: Raja Grafindo Persada.

Marsono. (2018). Fonetik. Yogyakarta: Gadjah Mada University Press.

Maryn, Y. (2009). Perturbation Measures of Voice: A Comparative Study between Multi-Dimensional Voice Program and Praat. Folia Phoniatrica et Logopaedica, 61 : 217-226.

Muslich, M. (2014). Fonologi Bahasa Indonesia : Tinjauan Deskriptif Sistem Bunyi Bahasa Indonesia. Jakarta: Bumi Aksara.

Pangesti, F. (2018). Senyapan dan Kilir Lidah Berdampingan dalam Produksi Ujaran. Hasta Wiyata, Vol 2, No. 1, hal. 8 - 17.

Prihartono, W. (2018). Identification of Latah Speech : Acoustic Phonetics Approach. Madah, Vol 8, No 2, hal 161-176.

Sudaryanto. (2015). Metode dan Aneka Teknik Analisis Bahasa : Pengantar Penelitian Wahana Kebudayaan secara Linguistis. Yogyakarta: Sanata Dharma University Press. 
